\title{
A new plesiosauroid from the Toarcian (Lower Jurassic) of Alhadas, Portugal
}

Adam S. Smith, Ricardo Araújo, and Octávio Mateus

Acta Palaeontologica Polonica 57 (2), 2012: 257-266 doi: http://dx.doi.org/10.4202/app.2011.0023

A partial plesiosauroid skull from the São Gião Formation (Toarcian, Lower Jurassic) of Alhadas, Portugal is re-evaluated and described as a new taxon, Lusonectes sauvagei gen. et sp. nov. It has a single autapomorphy, a broad triangular parasphenoid cultriform process that is as long as the posterior interpterygoid vacuities, and also a unique character combination, including a jugal that contacts the orbital margin, a distinct parasphenoid-basisphenoid suture exposed between the posterior interpterygoid vacuities, lack of an anterior interpterygoid vacuity, and striations on the ventral surface of the pterygoids. Phylogenetic analysis of Jurassic plesiosauroids places Lusonectes as outgroup to "microcleidid elasmosaurs", equivalent to the clade Plesiosauridae. Lusonectes sauvagei is the only diagnostic plesiosaur from Portugal, and the westernmost occurrence of any plesiosaurian in Europe.

Key words: Elasmosauridae, Plesiosauridae, Plesiosauria, Lusonectes sauvagei, plesiosaur, Jurassic, Toarcian, Lusitanian basin, Portugal.

Adam S. Smith [plesiosauria@gmail.com], Thinktank, Birmingham Science Museum, Millennium Point, Curzon Street, Birmingham, B4 7XG, UK; Ricardo Araújo [rmaraujo@smu.edu], Roy M. Huffington Department of Earth Sciences, PO Box 750395, Dallas, Texas, 75275-0395; and Museu da Lourinhã, Rua João Luis de Moura, 2530-157- Lourinhã, Portugal; Octávio Mateus [omateus@fct.unl.pt], CICEGe, Faculdade de Ciências e Tecnologia, Universidade Nova de Lisboa, 2829-516 Caparica, Portugal; and Museu da Lourinhã, Rua João Luis de Moura, 2530-157- Lourinhã, Portugal.

This is an open-access article distributed under the terms of the Creative Commons Attribution License (for details please see creativecommons.org), which permits unrestricted use, distribution, and reproduction in any medium, provided the original author and source are credited. 
FoF Full text (807.3 kB) 